\title{
Overcoming the Grammar Barrier in Foreign Language Learning: The Role of Television Series
}

\author{
Deborah Azaryad Shechter \\ Tel Aviv University \\ Correspondence concerning this article should be addressed to Deborah Azaryad Shechter, Division of \\ Foreign Languages, Tel Aviv University, P.O. Box 39040, Tel Aviv 6997801, Israel. \\ E-mail: deborah.shechter@gmail.com, ushechte@post.tau.ac.il
}

\begin{abstract}
Mastering the grammar of a foreign language requires learning the rules as well as the contexts within which the structures are used. Formal grammar instruction should therefore be augmented by exposing learners to authentic language. According to the literature, watching television series in the target language improves listening comprehension and enhances vocabulary acquisition. No study to date, however, has investigated the recursive use of one series, in the classroom and over an entire course, to explicitly teach grammar. Presenting apt pedagogical arguments substantiated by the literature on grammar instruction and evidence from the classroom, this article maintains that a television series can be an invaluable source of authentic language and an excellent means to teach grammar in context. It recommends using the dialogues in the scenes to teach and illustrate grammatical structures, especially those that are very different or do not exist in the learners' mother tongue. The article also proposes giving students pertinent writing tasks and adequate corrective feedback to help them internalize these structures. Consistent with recent studies indicating a strong connection between emotion and cognition, this method raises the students' motivation and enhances grammar learning; as such, it can supplant or complement conventional practices of grammar instruction and thereby warrants empirical studies. Finally, the article delineates directions for future research to elucidate how television series contribute to the teaching and learning of grammar.
\end{abstract}

Keywords: grammar learning, television series, communicative language teaching

Research has generally explored television with regard to incidental language learning. Drawing upon the findings of several studies, Richards (2015) reports that extensive television viewing as an outof-class activity fosters listening comprehension and vocabulary development. He points out the higher level of English fluency in countries where television films are not dubbed, indicating the effectiveness of extensive viewing. According to the literature, watching films in the target language improves listening comprehension (Cakir, \& Kana, 2015; Danan, 2004) and enhances vocabulary learning (Frumuselu, De Maeyer, Donche, \& Colon Plana, 2015; Linebarger, Moses, Garrity Liebeskind, \& McMenamin, 2013; Yuksel \& Tanriverdi, 2009). Studies also show that watching television series contributes to cultural awareness (Hammer, 2008; Iscan, \& Akturk, 2014). A comprehensive and insightful overview of the studies investigating the effects of films on language learning and critical accounts of their strengths and weaknesses can be found in Vanderplank (2010, 2016).
While previous studies have acknowledged the beneficial effects of television series on listening comprehension and vocabulary acquisition, their potential as a resource to explicitly teach grammar has been largely overlooked. One study attempted to see if children incidentally acquire grammatical rules following a short, subtitled movie and did not find any evidence for grammar learning (Van Lommel, Laenen, \& D’Ydewalle, 2006). The authors suggest that future research should examine whether grammar acquisition occurs 'with a sequence of several movies, spread over a longer period of time' (p. 255). A more recent study found that watching an enhanced subtitled video, combined with explicit teaching, helped students to better understand the context of the past perfect in English (Mohammed, 2013).

This article draws upon the performance and attitude of a second-year Turkish class (equivalent to A2/B1 of CEFR - the Common European Framework of Reference) at Tel Aviv University to present pedagogical arguments supporting the effectiveness 
of television series for grammar instruction, and thus attempts to fill an important gap in the literature. Scenes from a popular Turkish television series (Karadayi) that the author selected and transcribed became an integral part of our classroom lessons for the entire academic year. Approximately three times a month, we dedicated about half the class time (45 minutes) to watching a scene without captions or subtitles, reading the transcript, understanding the language, focusing on the grammatical structures, eliciting or explaining the rules, illustrating with more examples, and watching the scene again while rereading the transcript. The successful case of secondyear Turkish, both in terms of the students' positive attitude and their high achievement levels indicates that this method merits empirical studies. Therefore, this article is also an attempt to arouse the interest of the academic community to explore this arena more thoroughly and shed light on this promising resource for teaching grammar.

\section{Issues in the Teaching of Grammar}

\subsection{Different Approaches to Grammar Instruction}

Grammar is often a source of controversy among teachers and learners. Some students say they absolutely need rules and drills to learn grammar; others vehemently oppose rote learning, claiming that more intuitive and less structured ways work better for them. Although similar extreme positions may exist among teachers, many are looking for ways to reconcile the different learning preferences and help students from both camps within the same classroom. Research shows that teaching grammar works, while students can also learn a great deal of grammar naturally (Ellis, 2006). Ellis crystallizes the key issues in grammar instruction that still lack clear-cut solutions and recommends combining a variety of approaches to teach the grammar of a foreign language. He urges teachers to recognize why certain approaches work and others do not, so they can develop their own theories of grammar instruction.

\subsection{Grammar and Communicative Language Teaching}

Communicative language teaching (CLT) basically refers to language teaching practices that aim to foster a learner's ability to communicate in the target language. Richards (2006), in his comprehensive review of CLT and its relevance today, writes that grammatical competence, i.e., the knowledge of grammar rules and structures that enable the learner to produce correct sentences in the target language, is an essential step in language learning, but not sufficient by itself for communicative competence, i.e., the ability to use language for meaningful communication. According to Thornbury (1999), grammar is a resource for authentic communication, and in order to achieve communicative competence learners need to focus on form as well as on meaning. Likewise, Nassaji \& Fotos (2011) claim that form-focused instruction is particularly effective when incorporated into a meaningful communicative context. Within the CLT framework, grammar learning does not drive teaching practice but results from it. Prominent researchers in the field agree that grammar instruction must be included in CLT programs (Cullen, 2012; Ellis, 2006; Richards, 2006; Richards \& Reppen, 2014; Thornbury, 1999).

\subsection{The Gap Between Grammatical Knowledge and Grammatical Ability}

According to Richards \& Reppen (2014), we can view grammar both as knowledge and as an ability. Grammatical knowledge helps us produce grammatical sentences. Grammatical ability, on the other hand, helps us use grammar as a communicative resource to create spoken and written language. Similarly, according to Cullen (2012), grammar is a communicative resource that enables us to understand the language that we read or hear, and to be understood when we speak or write. As such, it is at the service of the language user, and communicative grammar instruction should reflect this. He explains that we exhibit grammatical ability when we use the correct grammatical forms in the correct context; that is, when we make the correct choices, not merely at the sentence level, but at the text level, both in speech and in writing (Cullen, 2012). Hence, when grammar is taught not in isolation but in a communicative context with real life examples, learners have a better chance to connect theory with practice, so that they will not only be able to read a text and understand it, but also understand spoken language, and speak pertinently and in a way that native speakers can understand. A communicative context can help learners bridge the gap between their grammatical knowledge and their grammatical ability.

The skill to make the correct choices when speaking and writing in a foreign language is not something one can take for granted. It often requires years of steady effort and practice. A foreign language is probably best learned in the country where it is spoken. However, a long-term stay in a foreign country is often a luxury that few foreign language learners can afford. Thus, many people study foreign languages in their country of residence where teachers do not only need to teach the grammar rules, structures, and vocabulary of the language, i.e., deliver formal language instruction, but also face the challenge of bringing the language to life for their students in a setting where the language is rarely heard or spoken. In less commonly taught languages (LCTLs) such as Turkish, the gap between 
grammatical knowledge and grammatical ability is often more acute.

The question arises as to what is an authentic communicative context that can bring a language to life for learners in a foreign country. In the past, classic audio-visual lessons attempted to simulate real life conversations to illustrate language use. Today, however, in our post-technological age where the Internet is ubiquitous, language teachers have easy access to authentic resources including spoken language through podcasts, commercials, news items, songs, and films. All of these can become excellent teaching materials, taking into account among others, the students' levels, fields of study, and the time available. An additional resource that language teachers can easily access on the Internet is television series. They constitute an authentic communicative context to assist with bridging the gap between the learners' grammatical knowledge and their grammatical ability.

\section{Television Series and Grammar Instruction}

\subsection{Rationale for Teaching with Television Series}

Television series in LCTLs like Swedish, Danish, Korean, Turkish, and others have achieved international success in recent years and can be watched freely on television in many countries. This article focuses on series and not on films or other programs. The recursive use of the same series which interests the class is an effective means to promote grammar learning. When the students are fascinated by the story and the characters, they look forward to these lessons. Unlike a film, which tells a story in two hours, the plot in a series develops more slowly and continues for many episodes. The teacher thus has a huge bank of scenes, rich in authentic language, from which lessons can be designed. Television series break the monotony of traditional classroom lessons and they can entertain and motivate the students. Some extremely popular series enslave the viewers, who happily follow them season after season. For our purposes, the addictive nature of a television series is an advantage. This is one addiction that has a positive outcome: learning a foreign language.

Until now, research has generally overlooked the potential of television series for teaching the grammar of a foreign language. Yet, when appropriately chosen for the student population and duly integrated into classroom instruction, they are an invaluable source of authentic language and an excellent means to teach and reinforce grammatical structures (e.g., word order, subordinate clauses) and verb forms (e.g., tenses, passives, subjunctives, conditionals), especially when these structures do not have an equivalent or are very different in the learner's mother tongue. This is the case for LCTLs such as Turkish, where the syntax is drastically different and completely counterintuitive to most learners. Teachers can avail themselves of television series as an innovative means to teach and illustrate grammar in a communicative context.

\subsection{Why Television Series Can Foster Grammar Learning}

This section is an account of why a television series is an effective tool for teaching grammar and why future research should investigate this resource more thoroughly. The discussion below is a dialogue with the literature on grammar pedagogy: first, the statements of previous research are presented and then, in order to clarify how they bear on television series, my arguments are conveyed in the bulleted paragraphs.

The need to bridge the gap between grammatical knowledge and grammatical ability is a recurring issue in recent research. In their practical book, Gerngross, Puchta \& Thornbury (2006) address the difficulty of transferring grammatical knowledge to effective use. In the opening, they state that the 'discrepancy between knowledge and putting it to use' (p. 5) led them to look for alternative ways to practice grammar more efficiently. They found the solution in language awareness activities and creative grammar practice imbued with imagination and humor. Advocating that grammar learning can be fun, the authors emphasize the importance of making the language in these activities as memorable as possible for effective learning.

- Grammar learning can indeed be fun. Television series have an infinite supply of memorable dialogues, enhanced with memorable acting and drama, in memorable settings, that contribute to effective learning. Evidence of this is the fact that students often remember chunks of speech and even full sentences from scenes that impressed them the most and later use these in speech or in writing.

Thornbury (2002) argues that a grammar-focused pedagogy enhanced and perpetuated by commercial grammar books delivering an 'atomized view of language' (p. 99), precludes authentic language use. A core assumption of current CLT is that 'meaningful communication results from students processing content that is relevant, purposeful, interesting, and engaging' (Richards, 2006, p. 23). In CLT, 'meaning is viewed as the driving force of learning' (p. 26).

- When students watch a television series, they experience authentic language. Their interest in the developing plot and the plight of the leading characters makes them want to understand everything. Meaning indeed becomes the driving 
force of learning, and thus grammar is neither the sole focus of the lesson, nor a deterring factor for students who are "afraid" of it. Television series help students move away from the fragmentized view of grammar books and acquire an integral view of the language. This exposure to real language prepares students for real communication in the target language by also developing their sociolinguistic and pragmatic competence.

A good pedagogy of grammar instruction should 'develop awareness of differences between spoken and written language' (Richards \& Reppen, 2014, p. 9). According to Cullen (2012), EFL course books are predominantly based on written grammar and generally ignore the distinctive features of spoken grammar.

- This is no doubt also true about course books in other languages. Yet, certain syntactic structures occur only in speech. When we adhere to grammar books, our students do not learn very important aspects of spoken language. Thanks to television series, students become familiar with the spoken grammar of the language, which is essential to achieve grammatical ability. For instance, although Turkish is categorized as SOV, verbinitial sentences are common in speech. Such sentences in the dialogues help students become aware of the pragmatic functions of Turkish word order. Another idiosyncrasy of Turkish, the suffix $-m I s$ (conveying the meaning of "I heard that" or "it turns out that") is very common and best illustrated in spoken language. Besides noticing syntactic differences between written and spoken language, students begin to make a connection between the written word and how it is pronounced. For instance, in spoken English 'going to' is often pronounced 'gonna'. Similar changes occur with many Turkish words or phrases, where the written form is different from the spoken form: değil mi sounds dimi; gideceğim sounds gidicem; ne yaplyorsun sounds naapyosun etc.

While discussing content-based instruction as an extension of CLT, Richards (2006) enumerates a number of processes from which language learning results. One of these is 'paying attention to the language one hears (input) and trying to incorporate the new forms into one's developing communicative competence' (p. 28).

- Television series have an infinite supply of auditory input with new structures for students to incorporate into their developing communicative competence, and therefore can contribute greatly to grammar learning.

'Learners need to be able to notice features of grammar in natural, realistic contexts of use' and classroom instruction should aim to speed up this process (Cullen, 2012, p. 260). Similarly, according to Richards \& Reppen (2014), teachers should 'provide opportunities for guided noticing' (p. 13). Furthermore, since noticing is 'fleeting', like attention (Vanderplank, 2016, p. 242), 'and very far from internalizing' (p. 243), the teacher should make sure that the students do not just notice the form but also learn its meanings and uses (Ellis, 2006). Thornbury (1999) calls this process of becoming aware of grammar 'consciousness-raising', and emphasizes that it is essential for learning to take place.

- Noticing is an important process in foreign language learning and a basic principle in grammar pedagogy. Television series provide ample opportunities for students to notice features of the foreign grammar as they occur in natural, realistic contexts. The students may notice and point out the structures to the teacher, or the teacher may lead the class to notice certain forms. If a structure has several uses/meanings, teachers can raise the students' consciousness by reminding them of other instances encountered, or illustrate the structure with examples from additional scenes and other authentic resources, such as online newspapers. This helps students internalize the new forms and promotes learning. According to Cullen (2012), learning results from opportunities to form hypotheses about how grammar works. Ellis (2006) and Cullen (2012) propose using both inductive and deductive methods. Similarly, Richards \& Reppen (2014) suggest that we use a variety of pedagogical approaches for teaching grammar.

- Television series afford students repeated opportunities to discern characteristics of the target language and to develop their own notion of how the language functions. They may reappraise and revise their hypotheses based on additional forms that they notice, and again when they become more proficient in the language. As in the case of noticing, the teacher can accelerate this process. When we use an inductive approach, we can try to elicit the rules from the students, which causes the class to be more alert and the lesson livelier. This process also gives the students a sense of achievement, increasing perceived self-efficacy which contributes to their motivation to learn (Bandura, 1993). When necessary, teachers can rephrase the rules and give additional examples to corroborate what the students have formulated. If the grammatical structure is one that can be more easily understood deductively, then teachers should choose that approach and save time.

Ellis (2006) holds that instead of trying to teach the entire grammar of a language, teachers should try to focus on grammatical structures that are known to be particularly problematic to learners. Similarly, 
Gerngross, Puchta \& Thornbury (2006) highlight English structures widely known to be difficult for learners of a variety of nationalities and show ways to teach these structures imaginatively and with humor.

- Television series provide an ideal context to achieve these goals. The dialogues in the scenes represent authentic, spontaneous language and, as such, they contain not only the most common structures that learners need in order to communicate, but also those that are challenging, completely different, or even inexistent in the learners' mother tongue. In the selected scenes, teachers can focus on the grammatical structures that they know to be problematic or that students point out as challenging. More time can be dedicated to the study of these structures depending on the students' needs and interests. This exposure to linguistic structures in their authentic communicative contexts, besides raising the students' awareness, helps them confirm what they already know and correct their previous misconceptions of these structures.

According to Richards \& Reppen (2014) grammar and vocabulary are often intertwined and making connections between grammar and vocabulary contributes to learning how to use grammar as a communicative resource.

- The authentic everyday conversations in the scenes often include grammatical structures that the students originally learned as vocabulary. For instance, students know colloquial expressions such as görüşürüz (see you), teșekkür ederim (thank you), geçmiş olsun (get well), kolay gelsin (good luck) before they learn the grammar in these expressions. When such grammatical structures occur in the dialogues, a language segment initially learned as a lexical item is now taught as grammar. The communicative context of the scene makes it easier for the students to understand the meanings/functions of the grammatical structure. According to Thornbury (1999), effective grammar teaching is one that arouses attention, provides good contextual information, and is memorable; to achieve this, teachers must create optimal conditions for learning with relevant and engaging materials that motivate the students.

- Scenes from a favorite television series that are highly engaging, reasonably challenging, and relevant to the students' needs fulfill the above conditions for effective grammar instruction. Thanks to the dramatic events and the authentic dialogues enhanced by the visual medium, grammar is no longer a set of rules to produce correct sentences yet divorced from other components of the language, but an integral part of successful communication.
The arguments above present a strong case for teaching grammar with television series. Any $21^{\text {st }}$ century instructional pedagogy that focuses on grammar as a communicative resource should integrate grammar with the four skills - reading, writing, listening, and speaking (Richards \& Reppen, 2014 among others). A television series constitutes an efficient method to achieve this goal, using a relatively small proportion of class time. Watching a scene and listening to the dialogue, reading the transcript and focusing on the grammar, followed by pertinent writing tasks and speaking activities can help students bridge the gap between their grammatical knowledge and their grammatical ability.

\subsection{Affective Aspects of Learning Grammar with Television Series}

Learning a language has a strong emotional side, similar to learning to play a musical instrument. It is common wisdom that in order to play an instrument well one has to love it. This view is also supported by research on neurobiology indicating a strong connection between emotion and cognition with clear implications for the role of affect in learning (Immordino-Yang \& Damasio, 2007). In any kind of learning one has ups and downs, and learning a language is no different. To be able to sustain the right atmosphere conducive to learning is perhaps a teacher's greatest challenge. Students are often tired from other courses or distracted due to personal reasons. Sometimes the language just becomes too much. This is especially true when learning a LCTL drastically different from one's mother tongue; students cannot rely on linguistic similarities that make the learning process easier. The teacher must acknowledge how challenging the language actually is and make it manageable for the students. When teachers are aware of their students' state of mind they can fine-tune the lessons accordingly.

A sound psychological argument supporting the use of television series in the classroom comes from popular science. In her New York Times bestseller, psychology professor Angela Duckworth (2016) writes that the secret to achievement is not talent or IQ, but a combination of passion and perseverance that she calls 'grit'. Based on empirical studies and interviews with high achievers, she concludes that loving what we do and working hard to achieve it account for our success more than any other attribute.

It has been my experience that particularly in the case of a LCTL like Turkish, the inability to cope with the grammar of the language can discourage students to the point of wanting to drop the course. When grammar is learned as a by-product of a fun activity, such as watching a fascinating television series, students develop perseverance of some kind. Because 
they are engaged in something they enjoy, they sustain an intrinsic motivation to learn the language. This, in turn, increases their willingness to try harder to understand the grammar in the dialogues. This quality of a television series makes it an invaluable resource for teaching a foreign language and specifically, its grammar.

The connection between emotion and cognition, and the importance of emotion in learning is also acknowledged in a recent article on Spanish as a foreign language. The author discusses the importance of affect in grammar learning and stresses the need to create optimal emotional conditions conducive to effective and long-lasting learning. While the article does not deal with television series, it has a similar approach to grammar instruction. The author suggests breaking the classroom routine by teaching grammar with innovative methods, such as games that surprise the students and arouse their curiosity (Mendez Santos, 2016).

\subsection{The Importance of Choosing the Right Series}

Television series have a universal appeal and many countries produce original series in the local language. Therefore, teachers of most LCTLs have a variety of series to choose from. When classes consist of students studying the same academic subject, teachers can choose field-specific series appropriate for their student population: youth series for teenagers, hospital series for nursing students, law series for law students, historical series for history students, etc. When students come from different disciplines, the series should be chosen with care to appeal to the entire class. An engaging story guarantees learning in a pleasant atmosphere. When the students love the series, they will be motivated to learn.

Before watching the first scene, it helps to give students some background information. The teacher can write a brief synopsis in simple language and familiarize the class with the main characters. I chose Karadayı, a crime drama taking place in Istanbul in the 1970s. I was watching it with great interest and it was appropriate for my class, consisting mostly of students in Middle East History, some of whom also take courses on Modern Turkey. In Karadayı, universal values such as integrity, honesty, the quest for justice, respect for parents, together with the suspense of the plot, the excellent acting, the beautiful Istanbul locations, and the developing romance between the hero and the heroin enchanted my students. When students form an emotional bond with the lead characters, follow the actors on social media, and watch the series in their leisure time, the teacher has surely made the right choice.

Anonymous language teachers all over the world are probably using television series in their lessons for different purposes, including grammar. In a post in the British Council magazine, an English teacher describes how she uses two minutes of a film to illustrate a grammar point that she is teaching (Urisman, 2014). She shows a clip to explain 'neither do I' from Sherlock, another clip that illustrates the use of tag questions from Mad Men, etc. However, I believe that using isolated scenes from many different series does not have the same motivating effect. My students' familiarity with the characters and their interest in the developing story created a low-stress, highinvolvement environment that is perfect for language learning. They were looking forward to our Karaday1 lessons and were always happy to watch a new scene. They did not even pay attention to how hard they were working on the language. Grammar learning was an outcome, enjoying the film came first.

Throughout the academic year, we viewed a total of 18 scenes that were rich in tension, aroused curiosity or induced laughter. In addition, they were not extremely complex in terms of linguistic structures. The length of the scenes varied from two to six minutes. Depending on its length, a scene had a word count between 120 to 480 words approximately (see Appendix B for a sample scene and transcript). Before the viewing, I gave the students a little background information to put the scene in the right context. Using one series throughout the course is crucial for meaning-driven learning; each scene is another piece in the puzzle. The series constitutes a content unit and is an integral part of the course curriculum. This is in line with content-based teaching, which better reflects the learners' needs and where language is used as a means to acquire information and not as an end in itself (Richards, 2006).

In the Internet era where learning management systems are increasingly replacing textbooks, we can turn a television series into teaching material by transcribing the dialogues and putting links to the relevant episodes/scenes on the course website. Most series are freely available on YouTube and dedicated websites. Ideally, the course website should have a separate unit for the series where all the links and the dialogue transcripts can be easily accessed. For a detailed account of a course site layout and how to incorporate a thematic unit, see Azaryad Shechter (2016).

\section{From Grammatical Knowledge to Grammatical Ability}

The ultimate purpose of learning grammar is to be able to use it to communicate. According to Richards \& Reppen (2014), a pedagogy of grammar instruction should 'provide opportunities for meaningful communicative practice' (p. 14) where learners share 
real information. Similarly, according to Cullen (2012), in order for learning to take place, one must practice using grammar in meaningful contexts. Cullen further asserts that practice is essential for the learner to acquire 'the ability to access language more or less automatically, without undue attention or conscious thought' (p. 261). Whereas learners of English, the lingua franca of the Internet and most of the world, may attain this ability after a few years of study, such a level of automaticity is an extremely ambitious goal for the learner of an LCTL like Turkish. Considering that the students in question are only in their second year of Turkish, they cannot be expected to have such a spontaneous ability in the spoken language. A more modest and realistic goal would be to expect the students to be able to use the grammatical structures for writing in meaningful communicative contexts. The writing assignments should be done outside the classroom, so as not to waste precious class time that can be dedicated to teaching and practicing. Furthermore, students should not feel pressured to think that they need to access language automatically. They can decide how much time to dedicate for the writing task, with as much care and conscious thought as they like. I always gave writing tasks for homework and was not concerned about their using machine translations, since digital translations from Hebrew or English into Turkish produce ungrammatical and often unintelligible sentences.

The various writing tasks that they were required to do throughout the year gave my students opportunities to put into practice the grammatical structures we studied in class. Furthermore, these performance tasks were an excellent means to assess their progress and to adjust my teaching goals. It was rewarding to see in their essays, words, expressions, verb forms, and other grammatical features that they had picked up from the dialogues in the scenes. The students reported that only when they attempted to actually write, did they begin to discover their weaknesses and where they needed more explicit teaching. Since each writing task was about 150 words and the topics were interesting and relevant, they wrote willingly and asked for more. They felt that their grammar improved greatly thanks to these tasks and the corrective feedback they were given. In my opinion, correcting student errors individually, or as a class activity (with the student's consent or in anonymity) is an indispensable component of a good pedagogy of grammar instruction. This is in line with Ellis (2006, 2008), who delineates the importance of corrective feedback in the teaching of grammar. Similarly, Richards \& Reppen (2014) recommend using student errors 'to inform instruction' (p. 18).

At the end of the year, the progress that some students had made was phenomenal. They were able to produce grammatically correct sentences putting into practice the most challenging aspects of Turkish grammar that we had targeted in the dialogues (e.g., word order, subject and object participles, passives, causatives, subordinate clauses, the uses of certain tenses). A detailed account of the writing tasks is beyond the scope of this article. I recommend Richards \& Reppen (2014) for a thorough discussion of pedagogically sound classroom practices to enhance language production.

\section{Directions for Research}

As previously stated, the literature so far has primarily explored the effects of extensive television viewing on incidental language learning outside the classroom. By contrast, this article argues in favor of selective-intensive viewing to intentionally teach grammar in the classroom. The arguments presented here rely on one teacher's successful experience with a small class, as evidenced by the students' enthusiasm in the classroom, their high performance levels, and the unanimous positive feedback that they gave during and at the end of the course. See Appendix A for a detailed account of the students' feedback.

What emerges is that watching television series indeed improves listening comprehension and enhances vocabulary acquisition, as previous studies have attested. What also emerges is that television series provide an excellent communicative context for explicit grammar instruction, an area that researchers have not yet probed. Often, the realities of the classroom inform theory and research. The literature on grammar instruction reviewed in this article and the successful experience of the second-year Turkish class at Tel Aviv University provide adequate grounds for further research on television series as a resource for teaching grammar.

Are transcripts of dialogues in a television series pedagogically superior to other texts? Empirical studies are called for with additional classes and control groups to compare the performance levels achieved by learners who are taught grammar with a television series and those who are taught using other resources. Future research should also try to explain if and how learning a foreign language with a television series helps students bridge the gap between their grammatical knowledge and their grammatical ability. In order to test the effectiveness of this method, studies must be carried out during an entire course and not for a brief instructional period. Furthermore, the differences in students' attitudes and achievement levels must be quantified with structured measures. Standardized questionnaires and performance tasks are needed to assess the differences in attitude and 
achievement, respectively. It may be particularly interesting to conduct a study with three groups, whereby the same grammatical structures are taught by (a) watching scenes from a television series and reading the transcripts, (b) reading the transcripts of these scenes like a play, without telling the students that this is actually from a television series, and (c) using grammar books and texts.

To help students internalize the grammatical structures, studies can also incorporate productive tasks, such as writing. In this case, the same writing tasks must be assigned to all three groups described in the previous paragraph, followed by the same types of corrective feedback as Ellis (2008) mapped out in his insightful typology. Alternatively, studies can be carried out with two groups, where both groups are taught the same grammatical structures with a television series but only one group receives supplementary writing tasks. In addition, at least one of the issues that Ellis (2006) raised in the conclusion of his article can be adapted to television series: How does teaching grammar with television series affect the acquisition of implicit knowledge?

Studies can also investigate the effect of viewing scenes from one series as opposed to scenes from many different series. I do not know how this will influence achievement outcomes, but I believe affective differences will emerge favoring the consistent use of only one series throughout the course. In other words, the bond that students form with the characters and their interest in the story have a motivating effect which cannot be achieved by showing a scene from a different series each time to teach or illustrate a particular grammatical structure.

Using a television series throughout a language course opens new research directions for investigating different aspects of language learning. For instance, how does this method affect the students' sociolinguistic and pragmatic competence? Learning is surely not a compartmentalized process. While we were focusing on the grammar in the scenes, the students were also paying attention to words, colloquial expressions, songs, poems, historical events, Turkish culture, traditions, etc. On many occasions, students expressed how much they appreciated this diversity of input and how helpful the series were in enriching their vocabulary and familiarizing them with Turkish values. With regard to vocabulary acquisition, field-specific series such as legal and medical dramas can surely enhance the learning of professional vocabulary. Researchers can investigate whether the use of the same series throughout the course has a stronger effect on vocabulary learning and retention. Studies can also explore the topic of cultural awareness among learners who were taught a foreign language with a television series and those who are taught with other methods. While learners of English can readily familiarize themselves with American culture or Western values in general, the cultures of many LCTLs are not as accessible. It is not surprising, therefore, that a television series in a LCTL contributes more significantly to the learners' cultural awareness.

The effects of teaching grammar with a television series can also be examined across populations. Studies can compare high school pupils with university students or adult learners in language classes. Researchers can also try to clarify the implications of using transcripts, as described in this paper, as opposed to captions or subtitles. Transcripts are convenient as students can take notes, highlight words, and read the entire dialogue again and again. Captions, if available, usually change too quickly for learners to be able to read. Are transcripts more effective for teaching grammar than captions or subtitles? Studies can also compare the use of captions in the target language with the use of subtitles in the learner's mother tongue.

An additional parameter and arguably the most important one in the success of any type of instruction is the teacher. Future research should take this into account, and if the same teacher does not teach both the experimental and the control groups then every effort must be made to assign to each group a highly enthusiastic teacher who will earn the trust of the students and motivate them to work hard. Ideally, teachers should be assigned to the groups where they will teach grammar through their preferred method. Thus, researchers will be assured that the teachers in the groups are doing their utmost, wholeheartedly.

The possibility should not be ruled out that my passion for Karaday, my enthusiasm in class, and my conviction that this was a sound way to teach grammar played a role in my students' motivation and how they performed throughout the course. While my belief is grounded in intuition, it is also supported by leadership studies. In their highly acclaimed book on leadership, former U.S. Navy SEALs Willink and Babin (2015) convincingly argued that when all other variables are controlled, the team leader is the sole factor that determines success or failure. Hence, when we, as 'leaders', slacken, it affects our students negatively; when we love and believe in what we do, we inspire and motivate our students. Therefore, future studies must also try to elucidate the teacher's role in the effectiveness of any teaching method, including the use of television series for grammar instruction.

A television series sometimes causes social and linguistic repercussions which researchers can look into. The universal appeal of a television series and its unifying effects are particularly salient in the Facebook forum titled 'Karadayi for English speakers'. Greeks, Turks, Arabs, Israelis, South Americans, and Canadians, 
along with fans from many other nationalities devotedly wrote on this forum to interpret the events, predict what will happen in the next episode, reassure one another with regard to worrying developments, criticize the scriptwriters, etc. It was a true support group that I silently followed, amused but also with admiration. Most of the fans around the world did not know any Turkish and they were nevertheless watching Karadayı directly from the Internet when it was aired on Turkish television, or as soon as it was on YouTube. The forum administrator would initially post a quick summary of the episode in English and some days later, the entire episode in English which she had translated. The passionate fans would wait for these translations impatiently and thank her ceremoniously. This social phenomenon was also linguistically interesting. Fans had acquired new jargon using Turkish words from the series, correctly and in the right context, particularly words with strong emotional connotations, to season their posts that were often in broken English.

The aforementioned is by no means an exhaustive list of research directions. The possibilities for research are vast and no doubt scholars will come up with creative ideas and conduct empirical studies with different populations, in a variety of languages, and with bigger samples that will contribute greatly to our understanding of television series as a teaching and learning tool.

\section{Conclusion}

Learning a foreign language is an exciting experience. It is a fantastic journey into a new culture, a means to get in direct contact with different customs and different people. Television series are a fun way to learn a language. They break the monotony of classroom lessons, arouse curiosity, and help students who are apprehensive about learning grammar. The authentic communicative context of the dialogues brings the language to life for the students, exposing them to the grammar of spoken language and familiarizing them with native pronunciation and intonation. Besides improving their linguistic competence, students also develop sociolinguistic and pragmatic competence in the target language. Watching scenes from a television series in the classroom raises the students' motivation and contributes to effective learning.

This article discussed television series as a communicative resource that can transform wellknown practices of grammar instruction and called on teachers and scholars of foreign language acquisition to explore how television series promote the teaching and learning of grammar. I encourage teachers to use television series for intentional language teaching and learning, in particular, to enhance the acquisition of grammatical structures and to improve grammatical ability. Although watching a film is a receptive task, reading the dialogues out loud, paying attention to grammatical forms, and learning their meanings and functions in an authentic communicative context, reinforced with writing tasks and speaking activities, can foster the learners' grammatical ability along the path to communicative competence. When we do not follow a particular grammar book, we let the dialogues in the scenes introduce the grammatical structures and delight in the serendipitous teaching opportunities that constantly come our way.

\section{References}

Azaryad Shechter, D. (2016). Blended learning course format on Moodle: A model for beginner level foreign language courses in higher education. Journal of the National Council of Less Commonly Taught Languages, 19, 183-209. Retrieved from http://www.ncolctl.org/files/jncolctl-vol-19/ Blended-Learning-Course-Format-on-Moodle.pdf

Bandura, A. (1993). Perceived self-efficacy in cognitive development and functioning. Educational Psychologist,28(2),117-148.http://doi.org/10.1207/ s15326985ep2802_3

Cakir, A. \& Kana, F. (2015). Yabancı Dil Olarak Türkçe Öğretiminde Video Kullanımının

Dinleme Becerisine Etkisi. [The effect of using video on listening skill in teaching Turkish as a foreign language.] International Journal of Language Academy, 3(3), 50-65. Retrieved from http://dx.doi. org/10.18033/ijla.278

Cullen, R. (2012). Grammar instruction. In R. J. (eds) Burns A (Ed.), Pedagogy and Practice in Second Language Teaching. Cambridge: Cambridge University Press, 1 (pp. 258-266).

Danan, M. (2004). Captioning and subtitling: Undervalued language learning strategies. Meta: Journal Des Traducteurs, 49(1), 67. http://doi. org/10.7202/009021ar

Duckworth, A. (2016). Grit: The power of passion and perseverence. Penguin, Random House, Ebury publishing.

Ellis, R. (2006). Current issues in the teaching of grammar: An SLA perspective. TESOL Quarterly, 40(1), 83-107. http://doi.org/10.2307/40264512

Ellis, R. (2008). A typology of written corrective feedback types. ELT Journal, 63(2), 97-107. http:// doi.org/10.1093/elt/ccn023

Frumuselu, A. D., De Maeyer, S., Donche, V., \& Colon Plana, M. del M. G. (2015). Television series inside the EFL classroom: Bridging the gap between 
teaching and learning informal language through subtitles. Linguistics and Education, 32, 107-117. http://doi.org/10.1016/j.linged.2015.10.001

Gerngross, G., Puchta, H., \& Thornbury, S. (2006). Teaching grammar creatively. Cambridge University Press.

Hammer,J.E.(2008). Culture via television :Investigating the effects of a German television serial on the perceptions of fourth-semester German language classes. University of Texas at Austin.

Immordino-Yang, M. H., \& Damasio, A. (2007). We feel, therefore we learn: The relevance of affective and social neuroscience to education. Mind, Brain, and Education, 1(1), 3-10. http://doi.org/10.1111/ j.1751-228X.2007.00004.x

Iscan, A. \& Akturk, Y. (2014). Televizyon dizilerinin Türkçenin yabancı dil olarak öğretiminde kullanımı: Seksenler dizisi örneği. [The use of television series in teaching Turkish as a foreign language: the example of Seksenler series.] International Journal of Language Academy, 2(4), 234-246. Retrieved from http://dx.doi.org/10.18033/ijla.154

Linebarger, D. L., Moses, A., Garrity Liebeskind, K., \& McMenamin, K. (2013). Learning vocabulary from television: Does onscreen print have a role? Journal of Educational Psychology, 105(3), 609-621. http:// doi.org/10.1037/a0032582

Mendez Santos, M. (2016). Gramática afectiva en contextos de instrucción formal de español como lengua extranjera (ELE). [Affective grammar in contexts of formal instruction of Spanish as a foreign language (ELE).] Nuevas Perspectivas En La Enseñanza Del Español Como Lengua Extranjera. Hesperia. Anuario de Filología Hispánica, 19(2), 5184.

Mohammed, R. F. (2013). The effectiveness of using subtitled video to teach grammar. (Unpublished M.A. thesis). Iowa State University, IA. Retrieved from http://lib.dr.iastate.edu/etd/13057

Nassaji, H., \& Fotos, S. (2011). Teaching grammar in second language classrooms integrating form-focused instruction in communicative context. Teaching Grammar in Second Language Classrooms Integrating Form-Focused Instruction in Communicative Context, I, 1-16.
Richards, J. C. (2006). Communicative language teaching today. Language Teaching, 25(2), 1-47. Retrieved from http://www.cambridge.org/elt/ teacher-support/pdf/Richards-CommunicativeLanguage.pdf

Richards, J. C. (2015). The changing face of language learning: Learning beyond the classroom. RELC Journal, 46(1), 5-22. http://doi. org/10.1177/0033688214561621

Richards, J.C., \& Reppen, R. (2014). Towards a pedagogy of grammar instruction. RELC Journal, 45(1), 5-25. http://doi.org/10.1177/0033688214522622

Thornbury, S. (1999). How to teach grammar. Longman. Thornbury, S. (2002). Training in instructional conversation. In G. Trappes-Lomax, H. \& Ferguson (Ed.), Language in Language Teacher Education. John Benjamins Publishing.

Urisman, S. (2014). How to use TV series, trailers and films in language class. The Voices Magazine, British Council. Retrieved from https://www. britishcouncil.org/voices-magazine/how-to-usetv-series-trailers-films-language-class

Van Lommel, S., Laenen, A., \& D’Ydewalle, G. (2006). Foreign-grammar acquisition while watching subtitled television programmes. The British Journal of Educational Psychology, 76(Pt 2), 243-58. http:// doi.org/10.1348/000709905X38946

Vanderplank, R. (2010). Déjà vu? A decade of research on language laboratories, television and video in language learning. Language Teaching, 43(1), 1-37. http://doi.org/10.1017/S0261444809990267

Vanderplank, R. (2016). "Effects of" and "effects with" captions: How exactly does watching a TV programme with same-language subtitles make a difference to language learners? Language Teaching, 49(2), 235-250. http://doi.org/10.1017/ S0261444813000207

Willink, J. \& Babin, L. (2015). Extreme ownership: How U.S. Navy SEALs lead and win. St. Martin's Press, Macmillan Publishers.

Yuksel, D., \& Tanriverdi, B. (2009). Effects of watching captioned movie clip on vocabulary development of EFL learners. Turkish Online Journal of Educational Technology, 8(2), 48-54. http://doi.org/1303-6521 


\section{Appendix A}

\section{Student feedback}

\section{Questionnaire responses}

One month before the end of the year, I asked the class to give me feedback on our lessons with Karaday. Out of the six students enrolled (five young women and one young man), four women were present on that day.

I told them they could write their answers anonymously and in their mother tongue. I was interested in their "gut feelings" and did not want the language difficulty to affect their writing. I hoped they would write spontaneously, the first thing that came to their mind, without putting their thoughts through any filter and without embellishing them. Furthermore, writing in their mother tongue would only take about five minutes. They complied willingly and wrote sincerely. Three of the students wrote their names on their response sheets. The truth is, since I knew them so well, I would have guessed who wrote what anyway.

\section{I showed the following questionnaire on the screen.}

What is your opinion on the use of Karadayl in the Turkish lessons? Write freely what comes to your mind. You can write in isolated words or in partial or complete sentences.

Did you like the lessons with Karadayl? Why?

Did they contribute to the learning of the Turkish language? Explain.

In your opinion, are there any other reasons for using Karadayı besides the language? Explain.

In your opinion, how often should it be used? If you think it should be used less often than we did this year, or not at all, please explain why.

Student A: Learning Turkish through Karadayı is great for a number of reasons:

1. To learn new syntactic structures that are used in spoken language.

2. To hear other Turkish people speak (besides Deborah) sharpens our hearing.

3. Vocabulary, of course.

4. It adds interest to the lesson and it's not dry like textbooks/worksheets.

5. It teaches a lot about Turkish culture, beyond the language.

6. If it were up to me, we would watch the entire lesson (:) but I am biased.
7. Suggestion for improvement. It could be time-consuming, maybe it can be given as homework: give us a scene to try to transcribe by ourselves. It's much more challenging and will teach us a lot, in my opinion.

Student B: Very, very beneficial. Besides adding variety to the lesson contents that are diverse regardless of Karadayl, the series allowed us to experience the language as it is spoken. In other words, the way it is actually spoken in real life, as opposed to the lesson where the teacher speaks slowly and clearly. I enjoyed the lessons with Karadayı for the reasons above. With regard to frequency, I think during the semester we watched one scene every week. This, in my opinion, is a logical frequency. Once every two weeks can also be fine, but less frequently than that seems a pity to me.

Student C: I enjoyed very much the fact that Karaday1 was incorporated into our Turkish lessons. First of all, it creates an immediate connection with the characters and a desire to get closer to Turkish culture and to understand daily life in Turkey.

Secondly, listening to speakers who speak freely (even if their Turkish is a little old-fashioned) contributes a huge lot to the learning of the language. It turns the language into something alive, changing, human, practical. It's really fun!

Likewise, listening to Turkish regularly helps to acquire common expressions and to begin to think in Turkish. That's what happened to me when I began watching the series at home, after the initial stimulation of watching it in class.

And I think it's an interesting and wonderful way to teach grammatical phenomena in the language.

I warmly recommend to continue this way!

Student D: The use of Karadayı has contributed a lot to my learning of Turkish. Reading the accompanying transcripts and watching the film helped me to connect the knowledge gained from reading with the spoken language, and I could identify the words in speech.

The series is interesting and teaches us not only the pronunciation of words, but also gives us an inside look into Turkish culture.

The frequency of three times a month worked well in my opinion, and helped a lot to foster my understanding and learning of the language.

In general, viewing a series contributes greatly to learning, and studying the language becomes a pleasant, light, and relevant experience. Thank you!

Student A was completely carried away by the series 
and also watched it at home, often without subtitles, as soon as a new episode was available on YouTube. She chose and transcribed a beautiful scene after the course had ended and emailed it to me for corrections. She and Student $\mathrm{C}$ (who also watched the series at home) had better speaking skills than the other four students in the class. The male student also watched the series outside the classroom. Thus, $50 \%$ of the students were watching Karadayı in their leisure time.

\section{End-of-the-year feedback}

As an essay-writing task and a component of the final grade, students were required to choose three tasks/activities in the course that they found particularly beneficial for their language learning and to write a brief essay in Turkish on each one, describing its benefits. Karadayı was mentioned by five of the six students as one of the three most beneficial language learning activities. Students A, B, C, and D rewrote and elaborated on the questionnaire responses in Turkish that they had written in their mother tongue a month earlier. The male student also chose Karadayı as one of the three most beneficial activities and emphasized, among others, the importance of exposure to daily spoken language.

\section{Oral comments}

The comments that the students occasionally made during the year reinforced my conviction that showing scenes from a television series is a sound method for teaching a language.

Student A commented that she watched a particularly emotional scene countless times and kept missing a word. One day, when she was watching with her earphones on, she finally discerned the word. It was a common word that she knew (hakikatler "realities, truths") but in a quickly uttered sentence she had been unable to make it out. On another occasion, she said that she wanted to ask me a grammar question, but she got her answer from Karadayı. It was about the location of the conditional suffix, and a conditional sentence in the episode she was watching that evening answered her question. The sentence was Karadayım dediyse, yapar "If my Uncle Kara said it, he will do it."

Student B said that even if one does not continue to watch the series outside the classroom, it makes the lessons more interesting.

Student C said that she continues to think in Turkish and has Turkish words in her mind for a few hours after she watches an episode. Many months after the course had ended, she told me that she was beginning to forget her Turkish, so she went back to watching the series and her Turkish quickly started to come back.

The male student contributed with his excellent grammatical/syntactic observations during the reading of the transcripts. For instance, he would point out the yes/no question particle $m I$ in the middle of a sentence, rather than at the end, where it normally occurs. This would be a good opportunity to explain the pragmatic function of word order in Turkish and how the meaning/focus of the sentence changes when a different word order is used. He also paid attention to grammar in the episodes that he watched at home and asked perceptive questions.

The female student who did not give any written feedback clearly enjoyed the Karaday lessons very much and told me so. She described herself as "not an intuitive learner" and that as far as syntax was concerned, she benefited particularly from grammar rules and traditional grammar drills.

Student D who described herself as "an intuitive learner" said that she was especially relieved when I started to teach grammar through Karadayl, because she did not like even the occasional fill-in-the blank or transformation exercises. She commented that the series brought life to her learning and that her mind opened up to the language. 


\section{Appendix B}

\section{Sample scene and transcript}

We viewed "the interrogation scene" from minute 49:19 to 51:32 in episode 77.

https://www.youtube.com/watch?v=3wMi-tqZXCk

After viewing the scene, I distributed the transcript of the dialogue. The students took turns reading the dialogue out loud. This short scene is rich in verb suffixes and other interesting grammatical features. We focused on the uses of $-m I s$, the place of the question particle $m I$, causatives, passives, and subjunctives. The students asked to view this scene three times.

Savcı: Bu sükûnetiniz beni daha da şüphelendiriyor, Mahir Bey.

Neticede baş şüpheli sizsiniz.

Cüneyt Yanbal'ı öldürmek isteyecek yegâne insansınız.

Söyleyin hadi! Hastaneden nasıl çıkardınız adamı?

Mahir: Ben mi çıkarmışım?

Kim görmüş?

Var mı şahidiniz?

Savc1: Soruları ben soruyorum, Mahir Bey!

Sizin vazifeniz hakikati söylemek!

Mahkûmu hastaneden kaçırdınız mı, kaçırmadınız mı?

Ona cevap verin!

Kemal: Savcı Bey...

Savc1: Bu ne densizlik efendi! Sorgu var burada sorgu!

Kemal: Kusura bakmayın!

Yasin Komiserim konuyla alâkalı olarak gönderdi beni efendim.

Savcı: Anlaşıldı. Çıkabilirsin.

Tanıdık geldi mi bunlar, Mahir Bey?

İsterseniz daha yakından bakalım.

Bunlar Cüneyt Yanbal'ın eşyalarıymış.

Boğaz'da bulmuşlar.

Gerçi siz biliyorsunuzdur.

Yalnız iyi akılmış!

Adamı tut, Boğaz’a at. Sulara gömülüp gitsin.

Ne ölüsünü bulsunlar, ne dirisini.

İş burada kapansın, sizin de içiniz soğusun. 